\title{
Labor Force of the Visegrád Group Countries in the Context of Demographic Changes-Selected Aspects
}

\author{
Skibiński Andrzej, Sipa Monika \\ Czestochowa University of Technology, Czestochowa, Poland \\ skibinskia@tlen.pl
}

\begin{abstract}
The process of reduction of the number of births, accompanied by longer life expectancy, will have serious consequences for the supply of labor force (shrinking of the working age population) on the future labor market. Labor market participation of the Visegrád Group residents is increasingly higher. In this situation, promoting labor market participation among the elderly seems a significant solution to mitigate the effects of population ageing. In view of the above, the aim of the paper is to present the impact of demographic changes on the size of labor force in the Visegrád Group countries.
\end{abstract}

Keywords: Labor force, labor market, demographic trends, population ageing, active population

\section{Introduction}

In the period of transformation, societies of these countries underwent deep demographic, economic and social changes. A low birth rate and an increased number and percentage of the elderly are phenomena that have been observed in the Visegrád Group countries for over ten years (Philipov \& Dorbritz, 2003; Frejka, 2008; Sobotka, 2008). They can cause certain difficulties in demographic development and pose a huge challenge for social and economic policies of these countries. After accession to the EU, unfavorable tendencies in population reproduction in the analyzed countries have continued, especially in the context of a labor force figure (Skibiński, 2009). This is a very important issue, as labor force depends, among other things, on a growth level of working age population. According to Holzer \& Serek (2000), " in the face of current changes in the population age structures, it is now necessary to strengthen the sense of intergenerational responsibility in the society for the elderly, but the role of social responsibility for their fate will probably grow". In view of the above, the main aim of this publication is to present the impact of demographic changes on the size of labor force ${ }^{1}$ in the Visegrád Group countries. For achieving this research objective, selected demographic indicators as well as labor market participation and employment indicators for specified study periods were analyzed. Special attention was given to analysis of determinants of labor market participation among population in these countries, as active population is often equated with real labor force. Due to a wide scope of the subject, this publication will present only the most significant relationships.

\section{Methodological information}

The quantitative and qualitative analyses used herein were conducted based on data from Eurostat and OECD Statistics statistical databases, taking into account demographic projections. Absolute increases and dynamics indicators (single base and chain ones) were the methods used for time series changes. The temporal scope of the analyses was largely determined by data accessibility and the fact that the Visegrád Group countries started the process of system transformation around the same time, joining the European Union in 2004. The year 1990 was chosen as the beginning of the period of temporal comparison. The following study periods were selected to indicate the dynamics of changes: (before the EU accession: 1990 - 2004 - it refers to demographic analysis), (after the EU accession: 2004 -2013, 2013 - 2060). For every of the characteristics discussed, spatial comparisons were made, with a country accepted as a comparison unit.

\footnotetext{
${ }^{1}$ Labor force (labor supply). Working age population actively participating in the labor market. For the purpose of this analysis, the working age is from 15 to 64 (after Eurostat).
} 


\section{Demographic trends in the Visegrád Group countries and their impact on labor force - quantitative dimension}

The dynamics of the process of population ageing can be considered in two aspects: as changes in the population age structure between two selected time periods or as continuous changes (e.g. annual) in the age structure, which form a trend (Kurek, 2008; Lutz, 2010). In general, the bigger the dynamics of the process, the bigger the increase in the share of the elderly and the share of young population. The relationship between the past and present development of the processes that are part of natural growth on the one hand and future age structures of population on the other hand is obvious and has a character of feedback. It is also obvious that both a low birth rate and increasing life expectancy contribute to the intensification of the process of population ageing from the bottom of the age pyramid (i.e. decreasing share of young people) and from the top of the age pyramid (increasing share of the elderly) (Jóźwiak, 2013). What is important for the demographic future in the countries analyzed is the pace of this process as well as the process of transformations of the population age structure, understood as changes in proportions of the different age groups. In view of the above, the starting point for analyses will be presentation of the population pyramid by age groups (figure 1) in the European Union countries.

Figure 1: Age structure of the population in 2013 and 2060 in UE 28

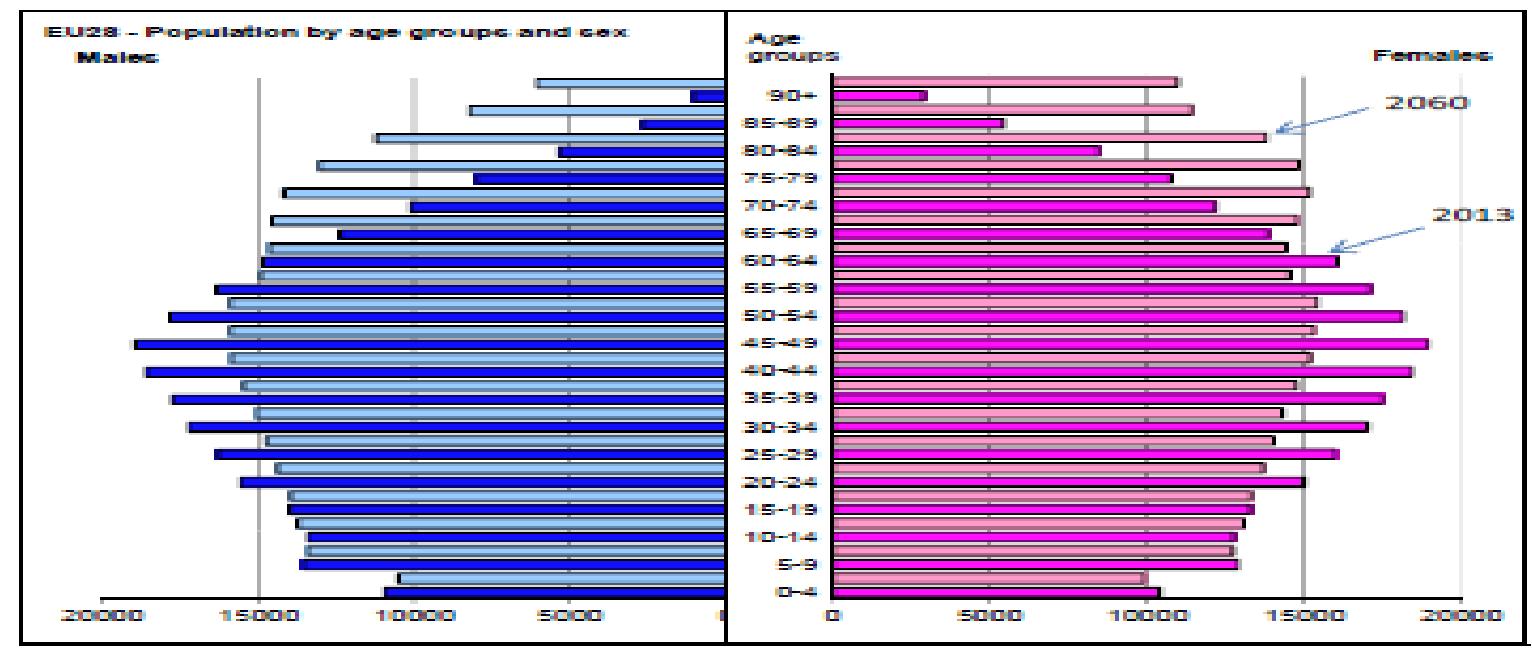

Source: Eurostat EUROPOP 2013 data

The population pyramid presented in fig 1 shows that the age structure of the EU population is projected to change dramatically. While in 2013 the most numerous cohorts for both males and females are around 45 years old, in 2060 the number of elderly people is projected to account for an increasing share of the population, due to the combination of the numerous cohorts born in the 1950's and 1960's and the continuing projected gains in life expectancy. At the same time, the base of the age pyramid becomes smaller due to below replacement fertility rates. As a consequence, the shape of the age-pyramids gradually changes from pyramids to more evenly sized pillars. The proportion of young people (aged 0-14) is projected to remain fairly constant by 2060 in the EU28 and the euro area (around 15\%), while those aged 15-64 will become a substantially smaller share, declining from $66 \%$ to $57 \%$. Those aged 65 and over will become a much larger share (rising from $18 \%$ to $28 \%$ of the population), and those aged 80 and over (rising from $5 \%$ to $12 \%$ ) will almost become as numerous as the young population in 2060 (The ageing report, 2014). This shows a clearly regressive character of the age structure of the population in the EU countries. Processes taking place in the Visegrád Group countries coincide with the general European tendency, but are more intensive. The phenomenon of labor force ageing was also evident when the analysis took into account the old-age-dependency ratio ${ }^{2}$, which data in Fig. 2 seems to confirm.

2 Old-age-dependency ratio. According to Eurostat, it is quotient of the number of people aged over 65 to the number of people aged 15-64. 
Figure 2: Old-age-dependency ratio in the Visegrád Group countries between 1990 and 2050 taking into account demographic projection
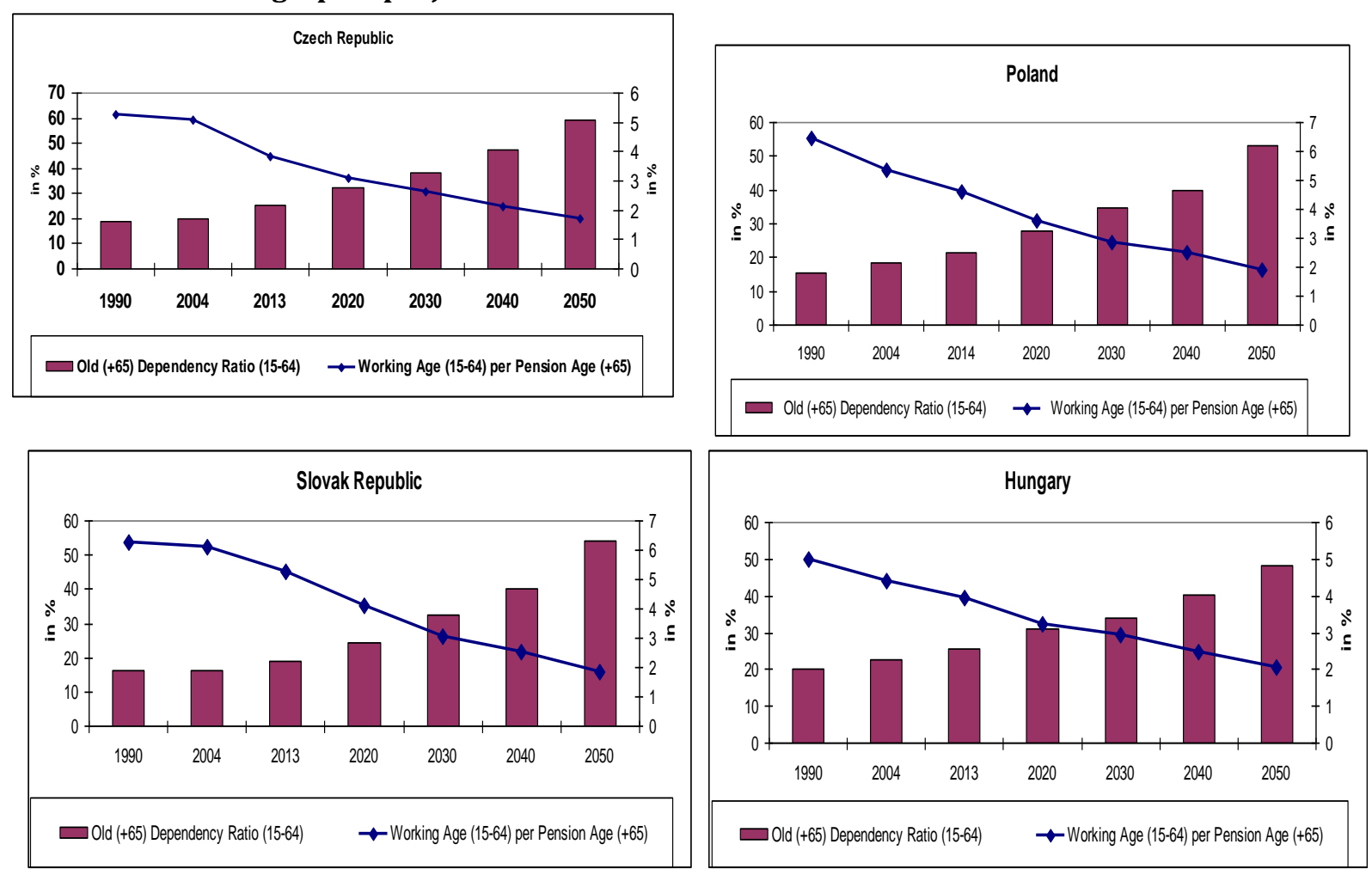

Source: Own study based on: Eurostat data

In the first analyzed period, i.e. 1990 - 2004, the pace of labor force ageing in the different countries was at a similar level, as shown by the values of the old-age-dependency ratio. We can thus see clear convergences between analyzed countries in this respect. However, the highest value in this period of analysis was recorded in Hungary and in the Czech Republic, whereas the lowest in Poland and Slovakia. In the second analyzed period (i.e. 2004 - 2013), the upward trend in the old-age dependency ratio in the countries examined increased. This process should be expected to intensify in the future, especially in Poland and Slovakia. By analyzing observed demographic changes, it is possible to predict not only further ageing of labor force, but also their shrinking, which data in table 1 seems to confirm.

Analysis of the data in table 1 allows a few important detailed conclusions to be drawn. First, between 2990 and 2004, a clear increase in the percentage of working age population can be observed. However, the growth rate of this population group varied in the countries analyzed. The biggest working age population growth occurred in Slovakia (growth by 11.7\%) and in Poland (growth by 7.7\%), whereas the lowest in Hungary (growth by $0.7 \%$ ) and in the Czech Republic (growth by 5.8\%). Second, between 2004 and 2013, the situation looked different. This period saw clear differences in the growth dynamics of working age population. Only Poland and Slovakia recorded a slight increase in this group of population. Third, projections data indicates that the above trends will continue, the labor force will further shrink and the overall population will decrease. We can thus conclude that the decrease in the working age population growth was especially visible in the analyzed countries after 2004. Among the causes of labor force ageing and shrinking are lower fertility rates and longer life expectancy. Table 2 presents selected demographic indicators for the Visegrád Group countries. 
Table 1: The number of working age population (15-64 years old) in the Visegrád Group countries in the periods 1990 - 2013 and 2013 - 2060, taking into account demographic projection

\begin{tabular}{|c|c|c|c|c|c|c|c|}
\hline \multirow[t]{2}{*}{ Years } & \multicolumn{3}{|c|}{ Working age population } & \multicolumn{3}{|c|}{$\begin{array}{l}\text { Working age population percentage in } \\
\text { the total population }\end{array}$} & \multirow{2}{*}{$\begin{array}{l}\text { Total } \\
\text { population } \\
\text { change } \\
(\text { in } \%) \\
1990=100\end{array}$} \\
\hline & $\begin{array}{l}\text { (in } \\
\text { thousands) }\end{array}$ & $\begin{array}{l}\text { Dynamics index } \\
\text { single base } \\
1990=100\end{array}$ & chain & in $(\%)$ & $\begin{array}{l}\text { Dynamics index } \\
\text { single base } \\
1990=100\end{array}$ & chain & \\
\hline \multicolumn{8}{|c|}{ Czech Republic } \\
\hline $1990^{*}$ & 6843,4 & 100,0 & - & 66,0 & 100,0 & - & in 2013 \\
\hline $2004 *$ & 7239,7 & 105,8 & 105,8 & 70,9 & 107,4 & 107,4 & $+1,2$ \\
\hline $2013^{*}$ & 7153,2 & 104,5 & 98,8 & 68,1 & 103,2 & 96,0 & \\
\hline $2020^{\wedge}$ & 6801,0 & 99,3 & 95,1 & 63,8 & 96,6 & 93,7 & in 2060 \\
\hline $2040^{\wedge}$ & 6619,0 & 96,7 & 97,3 & 58,0 & 87,9 & 90,1 & $-5,5$ \\
\hline $2060^{\wedge}$ & 6247,0 & 91,3 & 94,4 & 56,4 & 85,4 & 97,2 & \\
\hline \multicolumn{8}{|c|}{ Poland } \\
\hline $1990 *$ & 24794,0 & 100,0 & - & 65,2 & 100,0 & - & in 2013 \\
\hline $2004^{*}$ & 26720,0 & 107,7 & 107,7 & 70,0 & 107,3 & 107,3 & $+1,2$ \\
\hline $2013^{*}$ & 27148,0 & 109,5 & 101,6 & 70,5 & 108,1 & 100,7 & \\
\hline $2020^{\wedge}$ & 25456,0 & 102,7 & 93,8 & 66,3 & 101,7 & 94,0 & in 2060 \\
\hline $2040^{\wedge}$ & 22511,0 & 90,8 & 88,4 & 62,2 & 95,4 & 93,8 & $-12,7$ \\
\hline $2060^{\wedge}$ & 17951,0 & 72,4 & 79,7 & 54,1 & 83,0 & 87,0 & \\
\hline \multicolumn{8}{|c|}{ Slovakia } \\
\hline $1990 *$ & 3413,8 & 100,0 & - & 64,4 & 100,0 & - & in 2013 \\
\hline $2004^{*}$ & 3815,6 & 111,7 & 111,7 & 71,0 & 110,2 & 110,2 & $+2,2$ \\
\hline $2013^{*}$ & 3852,8 & 112,8 & 100,9 & 71,1 & 110,4 & 100,1 & \\
\hline $2020^{\wedge}$ & 3688,0 & 108,0 & 95,7 & 68,1 & 105,7 & 95,8 & in 2060 \\
\hline $2040^{\wedge}$ & 3203,0 & 93,8 & 86,8 & 62,8 & 97,5 & 92,2 & $-13,2$ \\
\hline $2060^{\wedge}$ & 2429,0 & 71,1 & 75,8 & 53,3 & 82,7 & 84,8 & \\
\hline \multicolumn{8}{|c|}{ Hungary } \\
\hline $1990^{*}$ & 6889,9 & 100,0 & - & 66,4 & 100,0 & - & in 2013 \\
\hline $2004^{*}$ & 6941,9 & 100,7 & 100,7 & 68,7 & 103,4 & 103,4 & $-4,7$ \\
\hline $2013^{*}$ & 6746,0 & 97,9 & 97,1 & 68,2 & 102,7 & 99,2 & \\
\hline $2020^{\wedge}$ & 6397,0 & 92,8 & 94,8 & 65,3 & 98,3 & 95,7 & in 2060 \\
\hline $2040^{\wedge}$ & 5809,0 & 84,3 & 90,1 & 61,1 & 92,0 & 93,6 & $-11,3$ \\
\hline $2060^{\wedge}$ & 5136,0 & 74,5 & 88,4 & 56,1 & 84,5 & 91,8 & \\
\hline
\end{tabular}

*real data 1990 - 2013

$\wedge$ prognostics data

Source: Own calculation based on: Eurost and OECD Statistics data.

Analysis of statistical data shows that life expectancy is getting systematically longer in the Visegrád Group countries. Projections data indicates a future increase in the average further life expectancy both among females (over 4 years on average) and males (over 6 years on average). This is a very positive tendency indicating civilization success. On the other hand, negative demographic trends include low fertility rate of the Visegrád Group countries' residents. It's worth noting that 25 years ago the fertility rate in most EU countries $^{3}$ exceeded 2 or was slightly below 2 (which ensured simple generational renewal) ${ }^{4}$. For comparison, in 2013 the fertility rate in the countries analyzed did not exceed 1.5. This shows that the issue of population ageing is becoming a key problem in the EU countries, especially in the Visegrád Group countries. Longer life expectancy on the one hand and low fertility rate on the other hand are two phenomena that have a significant impact on the increase in the number and percentage of people outside working age in

\footnotetext{
${ }^{3}$ Demographic stability is ensured by fertility rate of $2.1-2.15$, i.e. when in a given year there are 2 children on average per one female during the reproduction age (15 - 49).

${ }_{4}$ Explain the reasons for demographic change should be sought inter alia in the context of the demographic transition theory. The demographic transition theory (DTM) is a generalized description of the changing pattern of mortality, fertility and growth rates as societies move from one demographic regime to another. The term was first coined by the American demographer Frank W. Notestein in the mid-twentieth century, but it has since been elaborated and expanded upon by many others. Demographic changes observed in the the Visegrád Group countries are characteristic for fourth stage of demographic transition.(low fertility, low mortality, life expectancy is getting systematically longer).
} 
the whole population (Schmidt \& Vosen, 2013). Ageing recently became a very important policy issue, as it has wide-ranging implications in various areas of social, economic and political life. The most important sideeffects of the ageing process include (United Nations, 2005):

- increasing public expenditure on pensions, social security and health services, caused directly by the growing number of elderly (and thus of pensioners) in the population,

- a decreasing percentage of people in the working age, causing a shrinkage of the labor force and an increase in the overall burden on the working population in terms of various intergenerational transfers: taxes, other contributions, family support etc.,

- increasing risk of failure of repartition (pay-as-you-go) pension systems,

- growing demand for medical care and changing public health patterns (even though the elderly become relatively fitter and healthier),

- Increasing risk of the emergence of intergenerational conflicts, due to the changes in the patterns of resource distribution between the generations.

Summing up, the elderly age groups (65 years old and over) are increasing and will increase their share in the social structure in each of the countries analyzed, though with varying intensity.

Table 2: Selected demographic indicators for the Visegrád Group countries between 1990 and 2060

\begin{tabular}{|c|c|c|c|c|c|c|}
\hline \multirow[t]{2}{*}{ Years } & \multirow{2}{*}{\multicolumn{2}{|c|}{$\begin{array}{c}\text { Total fertility rate (TFR) } \\
\text { change }\end{array}$}} & \multicolumn{4}{|c|}{ Average further life expectancy } \\
\hline & & & Females & Males & $\begin{array}{l}\text { change } \\
\text { Females }\end{array}$ & Males \\
\hline \multicolumn{7}{|c|}{ Czech Republic } \\
\hline $1990 *$ & 1,90 & $2013-1990$ & 75,4 & 67,5 & $2013-1990$ & \\
\hline $2004^{*}$ & 1,23 & $-0,45$ & 79,1 & 72,5 & $+5,9$ & $+7,7$ \\
\hline $2013^{*}$ & 1,45 & & 81,3 & 75,2 & & \\
\hline $2020^{\wedge}$ & 1,63 & $2060-2013$ & 82,3 & 76,5 & $2060-2013$ & \\
\hline $2040^{\wedge}$ & 1,77 & $+0,35$ & 85,3 & 80,1 & $+6,6$ & $+8,1$ \\
\hline $2060^{\wedge}$ & 1,80 & & 87,9 & 83,3 & & \\
\hline \multicolumn{7}{|c|}{ Poland } \\
\hline $1990^{*}$ & 2,05 & 2013-1990 & 75,5 & 66,5 & 2013-1990 & \\
\hline $2004^{*}$ & 1,22 & $-0,77$ & 79,2 & 70,6 & $+5,7$ & $+6,5$ \\
\hline $2013^{*}$ & 1,28 & & 81,2 & 73,0 & & \\
\hline $2020^{\wedge}$ & 1,39 & $2060-2013$ & 82,2 & 74,5 & $2060-2013$ & \\
\hline $2040^{\wedge}$ & 1,53 & $+0,34$ & 85,3 & 78,8 & $+6,9$ & $+9,6$ \\
\hline $2060^{\wedge}$ & 1,62 & & 88,1 & 82,6 & & \\
\hline \multicolumn{7}{|c|}{ Slovakia } \\
\hline 1990* & 2,08 & 2013-1990 & 75,4 & 66,6 & 2013-1990 & \\
\hline $2004^{*}$ & 1,25 & $-0,74$ & 78,0 & 70,3 & $+4,7$ & $+6,3$ \\
\hline $2013^{*}$ & 1,34 & & 80,1 & 72,9 & & \\
\hline $2020^{\wedge}$ & 1,32 & $2060-2013$ & 81,1 & 74,3 & $2060-2013$ & \\
\hline $2040^{\wedge}$ & 1,44 & $+0,19$ & 84,5 & 78,6 & $+7,3$ & $+9,4$ \\
\hline 2060 & 1,53 & & 87,4 & 82,3 & & \\
\hline \multicolumn{7}{|c|}{ Hungary } \\
\hline $1990^{*}$ & 1,86 & 2013-1990 & 73,7 & 65,1 & 2013-1990 & \\
\hline $2004 *$ & 1,27 & $-0,51$ & 77,2 & 68,7 & $+5,4$ & $+7,9$ \\
\hline 2013* & 1,35 & & 79,1 & 72,2 & & \\
\hline $2020^{\wedge}$ & 1,50 & $2060-2013$ & 80,2 & 73,0 & $2060-2013$ & \\
\hline $2040^{\wedge}$ & 1,68 & $+0,39$ & 83,8 & 78,1 & $+13,3$ & $+16,9$ \\
\hline $2060^{\wedge}$ & 1,74 & & 87,0 & 82,0 & & \\
\hline
\end{tabular}

*real data $1990-2013$

^prognostics data

Source: Own calculation based on: Eurostat and OECD Statistics data. 


\section{Changes in labor market participation of people in the Visegrád Group countries after 2004}

The concept of labor market participation ${ }^{5}$ was defined in accordance with the methodology of the International Labor Organization and recommendations of Eurostat. EU labor force surveys are regulated by law. The main regulation implementing labor force survey in the European Community Member States is the Regulation of the European Council No. 577/98 of March 9th, 1998 on the organization of the labor force sample survey in the Community (as amended) ${ }^{6}$. Given the process of population ageing accompanied by the decrease in the number of working age people, the authors of this publication will focus on assessment of labor market participation in older age groups (i.e. 55 - 64 years old). The downward trend in labor market participation of people aged 55 and over has been present for many years in European countries with developed market economy, causing concern due to predicted decrease in the number of working age people and accelerated ageing of labor force and population. After 1989, similar changes have been observed in Central and Eastern European countries. According to Kotowska (2005), Fallick \& Pingle (2007), Leridon (2005), various activities undertaken in the 1990s in an increasing number of countries looking for ways to increase labor market participation of older people at working age reflect how important it is for governments to reverse the early retirement trend. Indications of reversal of this trend have been observed in EU countries from the second half of the 1990s.

Table 3: Labor force participation rate $^{7}$ in the Visegrád Group countries between

2004 and 2013

\begin{tabular}{|c|c|c|c|c|c|c|c|c|c|c|c|c|}
\hline \multirow[t]{3}{*}{ lata } & \multicolumn{12}{|c|}{ Activity rate in the age groups [in\%] } \\
\hline & \multicolumn{3}{|c|}{$15-64$} & \multicolumn{2}{|c|}{$15-24$} & \multirow[b]{2}{*}{$\begin{array}{l}\text { mal } \\
\text { e }\end{array}$} & \multicolumn{2}{|l|}{$25-54$} & \multirow[b]{2}{*}{$\begin{array}{l}\text { mal } \\
\mathbf{e}\end{array}$} & \multirow{2}{*}{$\begin{array}{l}55-64 \\
\text { total }\end{array}$} & \multirow[b]{2}{*}{$\begin{array}{l}\text { femal } \\
\text { e }\end{array}$} & \multirow[b]{2}{*}{ male } \\
\hline & $\begin{array}{l}\text { tota } \\
1\end{array}$ & $\begin{array}{l}\text { femal } \\
\text { e }\end{array}$ & $\begin{array}{l}\text { mal } \\
\text { e }\end{array}$ & $\begin{array}{l}\text { tota } \\
\text { l }\end{array}$ & $\begin{array}{l}\text { femal } \\
\text { e }\end{array}$ & & $\begin{array}{l}\text { tota } \\
\text { l }\end{array}$ & $\begin{array}{l}\text { femal } \\
\text { e }\end{array}$ & & & & \\
\hline \multicolumn{13}{|l|}{ UE 28} \\
\hline 2004 & 69,3 & 61,7 & 77,0 & 44,3 & 40,7 & 47,8 & 83,4 & 75,4 & 91,4 & 43,5 & 33,7 & 53,9 \\
\hline 2013 & 72,0 & 66,0 & 78,0 & 42,2 & 39,3 & 44,9 & 85,5 & 79,1 & 91,4 & 54,3 & 46,5 & 62,6 \\
\hline chang & $+2,7$ & $+4,3$ & $+1,0$ & $-2,1$ & $-1,4$ & $-2,9$ & $+2,1$ & $+3,7$ & 0,0 & +10 & $+12,8$ & $+8,7$ \\
\hline & & & & & & & & & & & & \\
\hline \multicolumn{13}{|l|}{$\begin{array}{l}2013- \\
2004\end{array}$} \\
\hline \multicolumn{13}{|c|}{ Czech Republic } \\
\hline 2004 & 700 & 622 & 779 & 352 & 315 & 387 & 878 & 809 & 946 & 451 & 313 & $60 ?$ \\
\hline 2013 & 72,9 & $\begin{array}{l}02,2 \\
65,1\end{array}$ & 80,5 & $\begin{array}{l}35,2 \\
31,5\end{array}$ & $\begin{array}{l}31,5 \\
26,1\end{array}$ & $\begin{array}{l}30,1 \\
36,8\end{array}$ & $\begin{array}{l}07,0 \\
89,1\end{array}$ & $\begin{array}{l}00,9 \\
81,9\end{array}$ & $\begin{array}{l}94,0 \\
95,8\end{array}$ & $\begin{array}{l}43,1 \\
54,8\end{array}$ & $\begin{array}{l}31,3 \\
44,2\end{array}$ & $\begin{array}{l}00,2 \\
66,1\end{array}$ \\
\hline chang & $+2,9$ & $+2,9$ & $+2,6$ & $-3,7$ & $-5,4$ & $-1,9$ & $+1,3$ & $+1,0$ & $+1,2$ & $+9,7$ & $+12,9$ & $+5,9$ \\
\hline & & & & & & & & & & & & \\
\hline \multicolumn{13}{|l|}{ 2013- } \\
\hline \multicolumn{13}{|l|}{2004} \\
\hline \multicolumn{13}{|l|}{ Poland } \\
\hline 2004 & 64,0 & 57,9 & 70,1 & 35,9 & 32,0 & 39,7 & 81,9 & 76,0 & 87,8 & 29,6 & 21,4 & 39,1 \\
\hline 2013 & 67,0 & 60,1 & 73,9 & 33,3 & 27,9 & 38,4 & 84,6 & 79,1 & 90,0 & 44,0 & 33,3 & 55,9 \\
\hline chang & $+3,0$ & $+2,2$ & $+3,8$ & $-2,6$ & $-4,1$ & $-1,3$ & $+2,7$ & $+3,1$ & $+2,2$ & +14 & $+11,9$ & +16 \\
\hline & & & & & & & & & & 4 & & 8 \\
\hline \multicolumn{13}{|l|}{ 2013- } \\
\hline \multicolumn{13}{|l|}{2004} \\
\hline \multicolumn{13}{|c|}{ Slovakia } \\
\hline 2004 & 69,7 & 63,0 & 76,5 & 39,3 & 35,7 & 42,9 & 88,9 & 84,1 & 93,8 & 31,7 & 14,8 & 51,9 \\
\hline
\end{tabular}

\footnotetext{
${ }^{5}$ Active population refers to all people participating in the labor market (employers, employees, self-employed, family members providing help free of charge) and registered unemployed. Active population does not include students learning profession, housewives or people living only on capital.

${ }^{6} \mathrm{http}: / /$ eur-lex.europa.eu/legal-content/EN/ALL/?uri=CELEX:32010R0220

${ }^{7}$ Labor force participation rate calculated as the relation of active population (i.e. working and unemployed) to the overall population for a given age group.
} 


\begin{tabular}{lllllllllllll}
\hline $\begin{array}{l}2013 \\
\text { chang }\end{array}$ & 69,9 & 62,5 & $\mathbf{7 7 , 2}$ & 30,8 & 23,7 & 37,6 & 87,2 & 80,5 & 93,6 & $\mathbf{4 9 , 5}$ & $\mathbf{4 0 , 4}$ & $\mathbf{5 9 , 5}$ \\
$\mathbf{+ 0 , 2}$ & $\mathbf{- 0 , 5}$ & $\mathbf{+ 0 , 7}$ & $\mathbf{- 8 , 5}$ & $\mathbf{- 1 2 , 0}$ & $\mathbf{- 5 , 3}$ & $\mathbf{- 1 , 7}$ & $\mathbf{- 3 , 6}$ & $\mathbf{- 0 , 2}$ & $\begin{array}{l}\mathbf{+ 1 7 ,} \\
\mathbf{+ 2 5 , 6}\end{array}$ & $\mathbf{+ 7 , 6}$ \\
$\mathbf{2 0 1 3 -}$ & & & & & & & & & & $\mathbf{8}$ & & \\
$\mathbf{2 0 0 4}$ & & & & & & & & & & & & \\
Hungary & & & & & & & & & & & \\
2004 & 60,5 & 54,0 & 67,2 & 27,9 & 24,3 & 31,4 & 77,9 & 70,9 & 85,0 & $\mathbf{3 2 , 0}$ & $\mathbf{2 5 , 8}$ & $\mathbf{3 9 , 7}$ \\
2013 & 65,1 & 58,8 & 71,7 & 27,2 & 24,0 & 30,4 & 83,2 & 76,9 & 89,4 & $\mathbf{4 1 , 7}$ & $\mathbf{3 4 , 8}$ & $\mathbf{5 0 , 2}$ \\
chang & $\mathbf{+ 4 , 6}$ & $\mathbf{+ 4 , 8}$ & $\mathbf{+ 4 , 5}$ & $\mathbf{- 0 , 7}$ & $\mathbf{- 0 , 3}$ & $\mathbf{- 1 , 0}$ & $\mathbf{+ 5 , 3}$ & $\mathbf{+ 6 , 0}$ & $\mathbf{+ 4 , 4}$ & $\mathbf{+ 9 , 7}$ & $\mathbf{+ 9 , 0}$ & $\mathbf{+ 1 0}$ \\
e & & & & & & & & & & & $\mathbf{5}$ \\
$\mathbf{2 0 1 3 -}$ & & & & & & & & & & & & \\
$\mathbf{2 0 0 4}$ & & & & & & & & & & & \\
\hline
\end{tabular}

Source: Own calculation based on: Eurostat and OECD Statistics data

Data presented in table 3 clearly indicates an increase in labor market participation among people aged 5564. This is very important given that labor force is ageing. The biggest growth was recorded in the Czech Republic and Slovakia, whereas the lowest in Hungary and Poland, where labor force participation rates, especially in the 55-64 age group, are among the lowest in the European Union. Clear differences in labor force participation are also seen as far as the gender is concerned - lower labor force participation rates are among females. In general, the employment rate of working age population in EU28 is above 70 percentage points, with low employment level among people from older age groups mainly contributing to the decrease of its value. Analyses also took into account employment rates (tab. 4)

Table 4: Employment rate ${ }^{8}$ in the Visegrád Group countries between 2004 and 2013

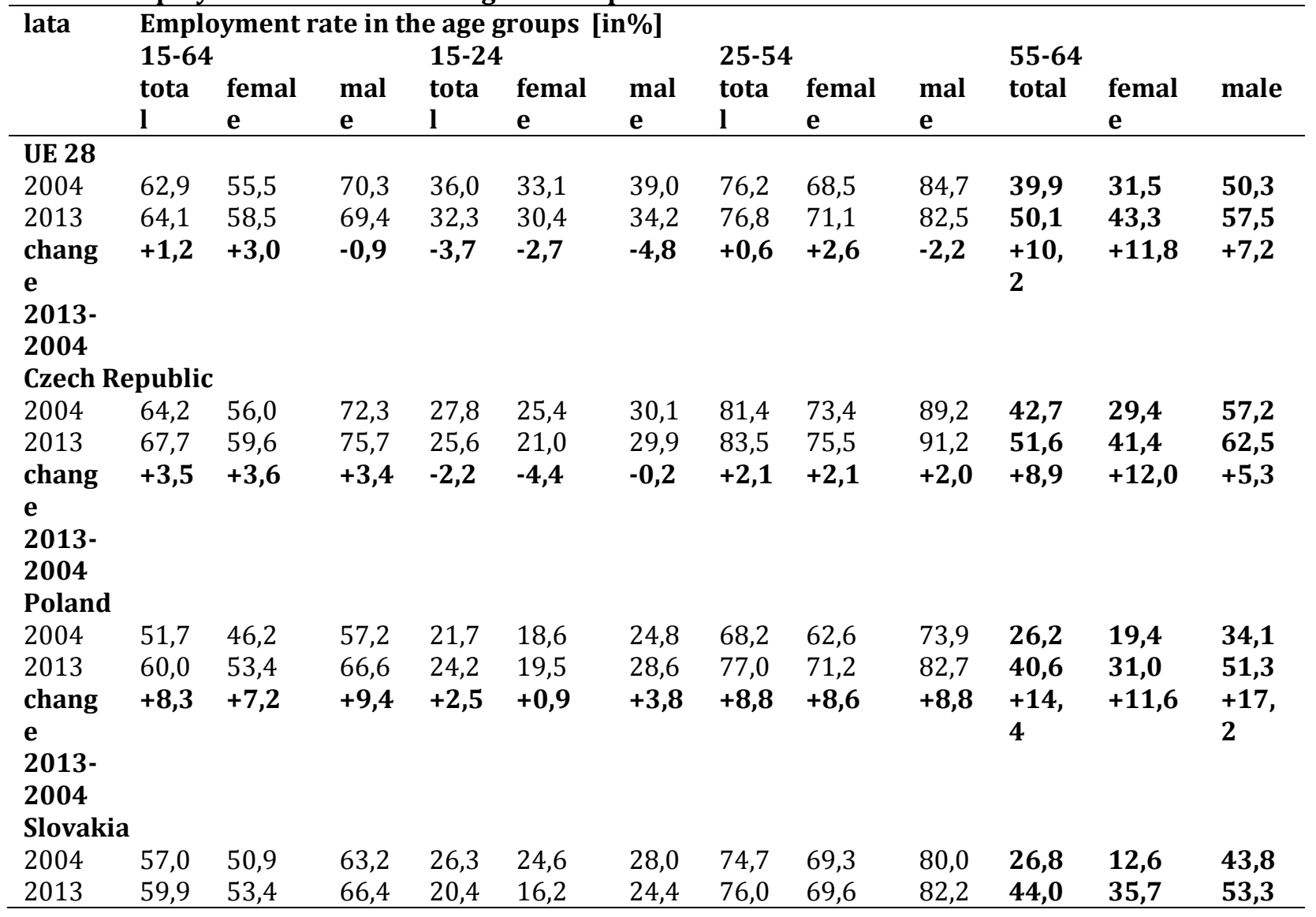

${ }^{8}$ Employment rate is calculated as a ratio of the number of those employed to the overall number of people from a given age group. 


\begin{tabular}{lllllllllllll}
\hline $\begin{array}{l}\text { chang } \\
\text { e }\end{array}$ & $\mathbf{+ 2 , 9}$ & $\mathbf{+ 2 , 5}$ & $\mathbf{+ 3 , 2}$ & $\mathbf{- 5 , 9}$ & $\mathbf{- 8 , 4}$ & $\mathbf{- 3 , 6}$ & $\mathbf{+ 1 , 3}$ & $\mathbf{+ 0 , 3}$ & $\mathbf{+ 2 , 2}$ & $\mathbf{+ 1 7 ,}$ & $\mathbf{+ 2 3 , 1}$ & $\mathbf{+ 9 , 5}$ \\
$\mathbf{2 0 1 3 -}$ & & & & & & & & & & $\mathbf{2}$ & & \\
$\mathbf{2 0 0 4}$ & & & & & & & & & & & \\
Hungary & & & & & & & & & & & \\
2004 & 56,8 & 50,7 & 63,1 & 23,6 & 20,8 & 26,3 & 73,6 & 67,0 & 80,5 & $\mathbf{3 1 , 1}$ & $\mathbf{2 5 , 0}$ & $\mathbf{3 8 , 4}$ \\
2013 & 58,4 & 52,8 & 64,3 & 19,8 & 17,2 & 22,4 & 75,5 & 69,8 & 81,1 & $\mathbf{3 8 , 5}$ & $\mathbf{3 2 , 3}$ & $\mathbf{4 6 , 2}$ \\
chang & $\mathbf{+ 1 , 6}$ & $\mathbf{+ 2 , 1}$ & $\mathbf{+ 1 , 2}$ & $\mathbf{- 3 , 8}$ & $\mathbf{- 3 , 6}$ & $\mathbf{- 3 , 9}$ & $\mathbf{+ 1 , 9}$ & $\mathbf{+ 2 , 8}$ & $\mathbf{+ 0 , 6}$ & $\mathbf{+ 7 , 4}$ & $\mathbf{+ 7 , 3}$ & $\mathbf{+ 7 , 8}$ \\
e & & & & & & & & & & & & \\
$\mathbf{2 0 1 3 -}$ & & & & & & & & & & & & \\
$\mathbf{2 0 0 4}$ & & & & & & & & & & & \\
\hline
\end{tabular}

Source: Own calculation based on: Eurostat and OECD Statistics data

The employment rate of males is higher than that of females. Lower employment rate among females results, among other things, from lower retirement age and specific biologic, economic, social and cultural factors, as: maternity, bringing up children, caring for dependants and performing other household duties to a much larger extent than males (D’Addio et al., 2010; Gorzeń - Mitka, 2014). The employment rate was systematically increasing, especially in the group of people aged 55-64. Expressed in percentages, over the study period, these increases were generally as follows: Czech Republic (20.8\%), Poland (54.0\%), Slovakia (64.1\%), and Hungary (23.8\%). Thus, analysis of employment rates for the period 2004-2013 shows that the upward trends in labor market participation of people aged 55-64 continued. The reversal of unfavorable trends in changes in labor market participation, in particular for older people at working age, may have resulted, among other things, from pension system reforms and labor market reforms implemented in several EU countries (more: Scherer, 2001; Stauner ,2008; Zsuzsa, 2013). In view of the above, duration of working life in the Visegrád Group countries was analyzed (table 5).

Analysis of data presented in table 5 shows that the period 2004-2013 saw an increase in the duration of working life of people in all the Visegrád Group countries. In EU-28 countries, the biggest increase, 2.5 year, is visible among females. Of the Visegrád Group countries, the biggest increase was recorded in Hungary (2.9 year) and in Poland (1.8 year), whereas the lowest in Slovakia (0.2 year) and the Czech Republic (1.3 year). In the male population, these increases were as follows: Hungary (2.7 year), Poland (2.2 year), the Czech Republic (1.5 year), Slovakia (0.6 year). The average age of exiting labor force among females also saw an increase. As far as the male population is concerned, the countries analyzed saw a slight decrease in duration of working life at the moment of exiting labor force. What's interesting, at the EU28 level, an upward trend was recorded (1, 3 years). Low access to current data in this respect makes analyses in this area difficult. However, the age at which people are going into retirement is moving upwards. A longer period of working life is a factor impacting labor force participation rates, especially for people aged 55-64 (OECD, 2013).

Table 5: Duration of working life (DWL ${ }^{9}$ ) in the Visegrád Group countries

\begin{tabular}{|c|c|c|c|c|c|c|}
\hline Country & \multicolumn{4}{|l|}{ Years } & \multicolumn{2}{|c|}{$\begin{array}{l}\text { Change } \\
2013-2004\end{array}$} \\
\hline \multicolumn{7}{|c|}{ Duration of working life (DWL) } \\
\hline & Females & Males & Females & Males & Females & Males \\
\hline EU 28 & 30,0 & 36,4 & 32,5 & 37,7 & $+2,5$ & $+1,3$ \\
\hline Czech & 30,2 & 36,3 & 31,5 & 37,8 & $+1,3$ & $+1,5$ \\
\hline \multicolumn{7}{|l|}{ Republic } \\
\hline Poland & 27,8 & 32,6 & 29,6 & 34,8 & $+1,8$ & $+2,2$ \\
\hline Slovakia & 29,8 & 35,2 & 30,0 & 35,8 & $+0,2$ & $+0,6$ \\
\hline Hungary & 25,5 & 30,4 & 28,4 & 33,1 & $+2,9$ & $+2,7$ \\
\hline \multicolumn{7}{|c|}{ Average age at the moment of exiting labor force } \\
\hline EU 28 & 60,4 & 61,6 & $61,3 *$ & $61,7^{*}$ & $+0,9$ & $+1,3$ \\
\hline
\end{tabular}

${ }^{9}$ DWL - indicator understood as the number of years of expected labor market participation of people aged 15 throughout their life. 


\begin{tabular}{lllllll}
\hline Czech & 59,1 & 62,3 & $59,6^{*}$ & $61,4^{*}$ & $\mathbf{+ 0 , 5}$ & $\mathbf{- 0 , 9}$ \\
Republic & & & & & \\
Poland & 57,4 & 62,0 & $57,5^{*}$ & $62,0^{*}$ & $\mathbf{+ 0 , 1}$ & $\mathbf{+ 0 , 0}$ \\
Slovakia & 57,6 & 61,1 & $57,5^{*}$ & $60,4^{*}$ & $\mathbf{- 0 , 1}$ & $\mathbf{- 0 , 7}$ \\
Hungary & 58,7 & 61,2 & $58,7^{*}$ & $60,1^{*}$ & $\mathbf{+ 0 , 0}$ & $\mathbf{- 1 , 1}$ \\
\hline
\end{tabular}

* data for 2011. (Change $2011-2004$ )

Source: Own calculation based on: Eurostat and OECD Statistics data

\section{Conclusion}

That's why active ageing policy becomes so important. Already in late 1990s, the European Commission developed a basis for nation-level activity in Europe as a response to the increasing problem of demographic ageing and proposed the implementation of policies to encourage older employees to stay at work as well as introduction of equal retirement requirements, specifying four key components (European Parliament resolution, 2012):

- increase in the employment rate of the elderly,

- reversal of the tendency to retire earlier,

- development of medical and social research to support healthy ageing and development of new prohealth tools,

- Fighting discrimination and social exclusion.

The analysis of quantitative data in the Visegrád Group countries shows that:

- The first period of the analysis (1990-2004) saw the biggest increase in working age population, decrease in fertility rate and longer average life expectancy. The analysis of the old-age-dependency ratio exposed the process of labor force ageing in the countries analyzed. Despite clear convergences between the Visegrád Group countries, there are differences in the intensity and dynamics of observed demographic tendencies.

- The second period of the analysis (2004-2013) saw a decrease in the dynamics of the increase in the number of working age population, which indicates shrinking of potential labor force in all the countries analyzed. The process of population ageing was even more evident. In the context of unfavorable demographic tendencies, there was an increase in labor market participation of people aged 55-64 and in employment rates.

Summing up, there is increasing awareness of the process of population ageing in the Visegrád Group countries, and strategies developed at the EU level are conducive to an increase in labor market participation, employment rate and longer working life, especially of older workers.

\section{References}

D'Addio, A. C., Keese, M. \& Whitehouse, E. (2010). Population Ageing and Labor Market", Oxford Review of Economic Policy, forthcoming.

European Parliament resolution on the demographic challenge and solidarity between generations (2010/2027(INI)) 2012/C 74 E/05

Fallick, B. \& Pingle, J. (2007). A cohort-based model of labor force participation, FEDS Working Paper No. 2007-09.

Frejka, T. (2008). Determinates of family formation and childbearing during the societal transition in Central and Eastern Europe. Demographic research, 19(1).

Gorzeń-Mitka, I. (2014). Bricolage in Family Business Management. Przedsiębiorczość Zarządzanie, T.15, cz.2, z.7, pp. 221-230

Holzer, J. Z. \& Serek, R. (2000). Sytuacja demograficzna świata i Polski w okresie do roku 2020,[in:]Strategia rozwoju Polski do roku 2020: Diagnoza ogólnych uwarunkowań rozwojowych, Komitet Prognoz „Polska 2000 Plus” przy Prezydium PAN, Warszawa, p. 25-62.

Jóźwiak, J. (2013). Demograficzne uwarunkowania rynku pracy w Polsce" [in]: Rynek pracy wobec zmian demograficznych. Red. Kiełkowska M. Wyd. Instytut Obywatelski, Warszawa, p. 9-23 
Kotowska, I. E. (2005). Older workers in the labor market and social policies, [in:] R. Schoenmaeckers, I. E. Kotowska, Population ageing and its challenges to social policy. Population studies 50, 117- 169

Kurek, S. (2008). Typologia starzenia się ludności Polski w ujęciu przestrzennym. Wyd. NAP Kraków, 74

Leridon, H. (2005). Reproduction and demography in Europe. International Congress Series 1279

Lutz, W. (2010). Emerging Population Issues in Eastern Europe and Central Asia. Research Gap on Demographic Trends. Human Capital and Climate Change. UNEPA

OECD. (2011). Trends in Retirement and in Working at Older Ages", in Pensions at a Glance: Retirementincome Systems in OECD and G20 Countries, OECD Publishing.

Philipov, P. \& Dorobitz, J. (2003). Demographic consequences of economic transition in countries of central and eastern Europe. Population studies, 39, 92-871

Scherer, P. (2001). Age of withdrawal from the labor force in OECD countries, OECD Labor Market and Social Policy Occasional Papers No 49

Schmidt, T. \& Vosen, S. (2013) Demographic change and the labor share of income. Journal of Population and Economy, 26, 357-378

Skibiński, A. (2009). Demograficzne uwarunkowania rynku pracy w Polsce na tle wybranych krajów Unii Europejskiej [in:] Barteczek A., Lorek A., Rączaszek A., Polityka Gospodarcza w Polsce i Unii Europejskiej na początku XXI w. AE Katowice, 419-427

Sobotka, T. (2008). The diverse faces of Second Demographic Transition in Europe. Demographic research, $19(1)$.

Stauner, G. (2008). The future of social security systems and demographic change. European View, 7, 203208

The ageing report. (2014). European Economy 8/2014

United Nations. (2013). Department of Economic and Social Affairs, Population Division

World Population Prospects. (2012). The Revision, Highlights and Advance Tables. Working Paper No. ESA/P/WP.228.

Zsuzsa, S. (2013).Challenges of Ageing Societies in the Visegrad Countries: Hungary, Czech Republic, Poland, Slovakia Hungarian Charity Service of the Order of Malta, Budapest. 